\title{
EFFECTS OF CLIMATIC VARIABILITY ON CASSAVA PRODUCTION IN NIGERIA
}

\author{
Fatai Abiola Sowunmi ${ }^{1 \bowtie}$, Oluwaseun Temitope Adeyemi ${ }^{1}$, Abeeb Adetunji Bello ${ }^{1}$ \\ ${ }^{1}$ University of Ibadan, Nigeria
}

\begin{abstract}
Climate change has brought about an irregularity in pattern and intensity of climatic variables, such as rainfall and temperature, which are important in crop production, making planning in agriculture difficult. The importance of cassava in the diet of Nigerians and its industrial use created a need to examine the effects of climatic variability on cassava production. Secondary data obtained from the Nigerian Meteorological Agency (NIMET) were used for the study. An analysis of variance and error correction model was utilised. The study showed that the rainforest zone had the highest averages of annual rainfall $(1,709 \mathrm{~mm})$ and relative humidity $(82.1 \%)$, while the Sahel savannah had the highest mean annual temperature $\left(35.3^{\circ} \mathrm{C}\right)$. The variability in annual rainfall and relative humidity was low in the rainforest zone. The study showed that the rainforest zone had the least dispersion of average annual relative humidity $(2.06 \%)$ while the Guinea savannah had the highest dispersion (4.68\%). The average cassava output from the agro-ecological zones was 49,118,871 MT per year. Rainforest and Guinea savannah accounted for $56.3 \%$ and $41.9 \%$ of total cassava output respectively. There were significant variations in the climatic variables (rainfall and temperature) among the agro-ecological zones but not significant among the years $(p>0.05)$. The annual rainfall and solar radiation were the factors that influenced cassava output in all the agroecological zones. Affordable irrigation systems available to cassava farmers and the adoption of climate-smart agriculture are recommended to boost cassava production in Sudan savannah and Sahel savannah.
\end{abstract}

Keywords: cassava production, co-integration, agro-ecological zones, climatic variables

\section{INTRODUCTION}

The Nigerian agriculture (crop subsector) is majorly rain-fed and practically dependent on the vagaries of the weather, especially rainfall, which has become more pronounced in the recent years due to climate change. The pattern of rainfall varies from one agro-ecological zone to another, due to this variability in rainfall pattern; tuber crops, including yam and especially cassava, are predominantly cultivated in the southern part of the country, though some states in the northern and central part of the country (Kwara, Benue, Kogi, Plateau, Taraba and the southern part of Adamawa) cultivate cassava in commercial quantities (Ogungbenero and Morakinyo, 2013). Moreover, the Food and Agricultural Organisation report (FAO, 2015) affirmed that over $60 \%$ of the total cassava production in Nigeria is carried out in the rainforest agro-ecological zone, while the rest $(40 \%)$ is produced in the moist savannah zones.

Cassava is the third-largest source of food carbohydrates in the tropics, after rice and maize. It is a major staple food in the developing world, providing a basic diet for over half a billion people (Fauquet and Fargette, 1990; FAO, 1995). Philip et al. (2005) revealed that the average per capita cassava consumption per person per day in rural and urban areas in Nigeria are $239.74 \mathrm{gm}$ and 213.76 gm respectively. The influence of weather and climate on the different components of crop production varies (Toshichika and Navin, 2015). Different types of climatic extremes can affect crop production

\footnotetext{
×atai Abiola Sowunmi, Department of Agricultural Economics, University of Ibadan, Ibadan, Nigeria, e-mail: fasowunmi@ live.co.uk, https://orcid.org/0000-0003-4108-8830
} 
differently. Irregularity of rainfall, emergence of different rainfall patterns from the ones that farmers are used to and unexpected dry spells have contributed to risks involved in crop production in general, and cassava production in particular. The Intergovernmental Panel on Climate Change (IPCC, 2001) estimated that climate change is likely to reduce yields and/or damage crops in the 21 st century. The effect of climate variability and climate change on crop yield has been a subject of long-standing interest as climate is a primary determinant of agricultural productivity. There is scant literature on the trends of climatic variables and effects of climate variability on the production of cassava, considering its importance in terms of food security and its potential as a huge foreign-exchange earner. This study is an attempt to determine the climatic and agronomic factors' influence on cassava production in different agro-ecological zones where its cultivation takes place.

\section{THEORETICAL FRAMEWORK AND LITERATURE REVIEW}

There are two theories underlining this study. These are theories of production and adaptation to climate change. Production is a process by which inputs and resources are transformed into outputs. A production function describes the technical relationship that transforms input (resources) into outputs (commodities). Beside the conventional inputs of land, labour, capital and management, climatic factors (rainfall, humidity, sunshine and temperature) and agronomic factors (topography, soil type) are also significant (Ben, 2019).

The production function where there are several inputs is represented as:

$$
y=f\left(x_{i}, m_{i}\right)
$$

where:

$y$ - represents the output

$x_{i}$ - represents the conventional inputs (land, labour, capital)

$m_{i}-$ represents the climatic factors (rainfall, temperature and humidity among others).

Adaptations are changes in behaviour and capital motivated by climate change. Economic theory suggests that adaptations are efficient (desirable) only if their benefit exceeds their cost. An understanding of how climate directly affects households is needed in order to understand how households will respond to its variability. A utility function is presented below:

$$
\operatorname{MaxU}(X, C) \text { s.t } \quad Y=P X
$$

where:

$U$ - represents a utility function that entails goods $(X)$ but contains climate $(C)$

$Y$ - represents income, which determines the budget constraints

$P-$ represents the vector of prices.

Using Roy's identity, a demand function can be identified for individuals as:

$$
\begin{gathered}
X_{1}=D_{1}(P, Y) \\
X_{2}=D_{2}(P, Y, C)
\end{gathered}
$$

For the vector of goods $X_{1}, C$ will not play a role. The desire for many goods such as transport or staples will not be climate sensitive. Households want to purchase the same quantity of these goods no matter the change in climatic factors. However, for another vector of goods, $X_{2}, C$ will shift the demand function, for example, households may want the same quantity of cassava end product (examples are garri and starch) at the same price in a long period of dry spell which makes harvesting difficult (Mendelsohn, 2012). Given the price garri/ starch, the household will have to reduce their demand or pay more to have the same quantity of the product because of reduction in supply brought about by climate change.

Various analytical tools have been used in studies on the effect of climatic variability on agricultural production. These tools include a coefficient of variation (Ayanlade et al., 2010; Girma et al., 2016; Kimengsi and Ngong, 2013), two-way analysis of variance (ANOVA) (Sowunmi and Akintola, 2010; Oluyole, 2010; Kansiime et al., 2013; Nyatuame et al., 2014; Gebrehiwot and van der Veen, 2013) and a co-integration analysis (Amos and Thompson, 2015; Amikuzono and Donkoh, 2012; Chikezie et al., 2015; Ayinde et al., 2013). The coefficient of variation in particular has been widely used to determine the extent of climatic variability. However, a known limitation of the coefficient of variation is that when the average value is zero, the value of coefficient of variation approaches infinity, and thus, it is quite sensitive to small changes in mean values. Furthermore, an analysis of variance is designed to test against any 
and all alternatives to the null hypothesis and thus may be suboptimal for testing against specific hypothesis. The coefficient of variation and ANOVA do not address the causal relationship between variables (e.g. agricultural output and climatic variables). The use of co-integration regression analysis in this study makes it possible to establish linear combinations in series that may not be stationary (Ayinde et al., 2011). The need to test for stationarity of time series data in order to prevent spurious regression is addressed by the co-integration regression analysis.

\section{MATERIALS AND METHODS}

The study covered five of the agro-ecological zones (rainforest, Guinea savannah, montane, Sudan savannah and Sahel savannah) in Nigeria where cassava is cultivated. Generally, cassava is grown in all the five agro-ecological zones under consideration. The data used for the study were secondary data obtained from the National Bureau of Statistics (NBS) and the Nigerian Meteorological Agency (NIMET). Data obtained from NIMET were climatic characteristics (annual average temperature, annual maximum temperature, annual rainfall, annual relative humidity and annual radiation) for the agro-ecological zones from 1995 to 2015. Agronomic characteristics (Cassava production intonnes and size of land used for cassava production within the same period) were obtained from NBS.

Data were analysed using descriptive statistics to profile climatic and agronomic characteristics of each of the five agro-ecological zones. Variations in climatic and agronomic variables among the agro-ecological zones were tested using ANOVA, while the variability in climatic variables within each zone was estimated using the coefficient of variation. The short- and long-run dynamic relationships between cassava output and the independent variables (climate variables and agronomic factors) in each agro-ecological zone were determined using a co-integration regression analysis. The co-integration analysis which gave a long-run dynamic relationship was determined as follows:

$$
\begin{array}{r}
L n C O T=\beta_{0}+\beta_{1} L n L S_{t}+\beta_{2} L n A A T_{t}+\beta_{s} L n A A R_{t} \\
+\beta_{4} L n A R H_{t}+\beta_{s} L n A R D_{t}+\beta_{6} L n A M T_{t}-\mu t
\end{array}
$$

The error correction equation (short-run dynamic relationship) is given as:

$$
\begin{aligned}
& \Delta L n C O T=\beta_{o}+\sum_{i=1}^{p} \beta_{i} \Delta L n L S_{t}+\sum_{i=1}^{p} \beta_{2} \Delta L n A A T_{t} \\
& +\sum_{i=1}^{p} \beta_{3} \Delta L n A A R_{t}+\sum_{i=1}^{p} \beta_{4} \Delta L n A R H_{t}+\sum_{i=1}^{p} \beta_{s} \Delta L n A R D_{t} \\
& +\sum_{i=1}^{p} \beta_{6} \Delta L n A M T_{t}+\omega E C M_{t}-1+\mu t
\end{aligned}
$$

where:

COT - represents the cassava output ( $\mathrm{t}$ )

$L S$ - represents the annual hectares of land used for cassava cultivation (ha)

$A A T$ - represents the average annual temperature $\left({ }^{\circ} \mathrm{C}\right)$

$A A R$ - represents the average annual rainfall $(\mathrm{mm})$

$A R H$ - represents the average annual relative humidity $(\mathrm{mm})$

$A R D$ - represents the average annual radiation $\left(\mathrm{W} / \mathrm{m}^{2}\right)$

$A M T$ - represents the average annual maximum temperature $\left({ }^{\circ} \mathrm{C}\right)$.

\section{RESULTS AND DISCUSSION}

The mean annual rainfall in the cassava cultivating agro-ecological zones of Nigeria from 1995-2015 was $1,220.4 \mathrm{~mm}$. The rainforest zone had the highest annual rainfall $(1,709.6 \mathrm{~mm})$, while the Sahel savannah had the lowest annual rainfall $(633.9 \mathrm{~mm})$ (see Fig. 1).

The rainforest zone had the lowest variability in the annual rainfall (8\%), while the Sahel Savannah had the highest variation (21.14\%) in the periods under consideration (see Table 1).

The mean annual temperature in the cassava cultivating agro-ecological zones of Nigeria from 1995-2015 was $26^{\circ} \mathrm{C}$. The Sahel Savannah zone recorded the highest annual temperature $\left(28.78^{\circ} \mathrm{C}\right)$, while the montane zone had the lowest annual temperature $\left(20.08^{\circ} \mathrm{C}\right)$ (see Fig. 2). The coefficient of variation revealed that the Sudan Savannah zone had the lowest variation of average annual temperature $(2.58 \%)$ while the Sahel Savannah zone recorded the highest variability (5.3\%) (see Table 2).

The mean annual relative humidity in the cassava cultivating agro-ecological zones of Nigeria from 19952015 was $57 \%$. The rainforest zone had the highest average annual relative humidity $(82.1 \%)$, while the Sahel savannah had the lowest $(37.7 \%)$ in the period of this study. The result showed that the rainforest zone had the least dispersion of average annual relative humidity $(2.06 \%)$ while the Guinea savannah had the highest dispersion (4.68\%) (see Table 3). 
Sowunmi, F. A., Adeyemi, O. T., Bello, A. A. (2020). Effects of climatic variability on cassava production in Nigeria. J. Agribus. Rural Dev., 3(57), 327-335. http://dx.doi.org/10.17306/J.JARD.2020.01373

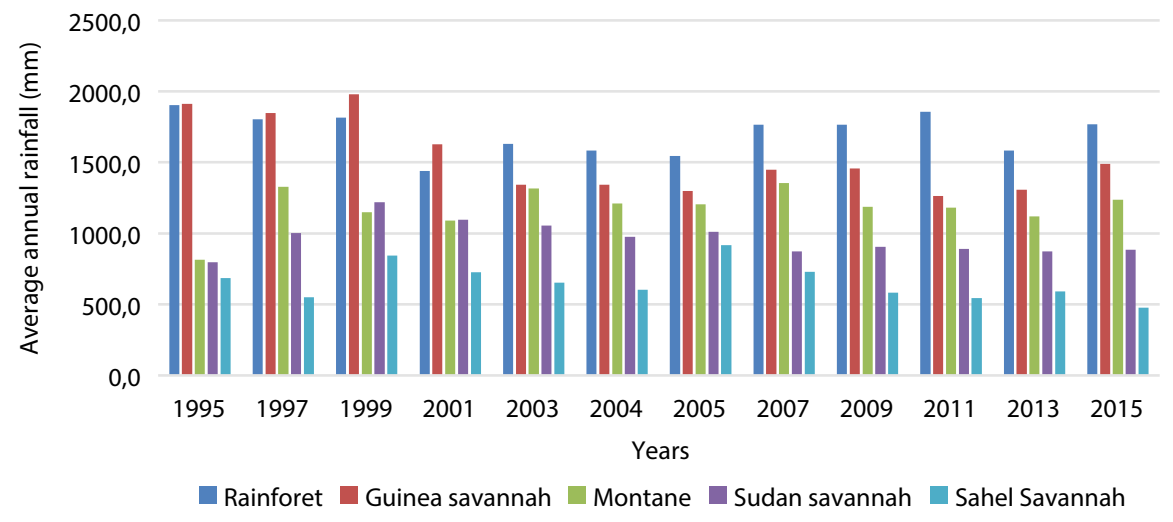

Fig. 1. Distribution of the average annual rainfall by agro-ecological zones (1995-2015) Source: result of data analysis, 2017.

Table 1. Ranking of average annual rainfall and coefficient of variation

\begin{tabular}{lrrrr}
\hline $\begin{array}{c}\text { Agro-ecological } \\
\text { zones }\end{array}$ & $\begin{array}{c}\text { Ranking of average } \\
\text { annual rainfall } \\
(\mathrm{mm})\end{array}$ & $\begin{array}{c}\text { Ranking of coeffi- } \\
\text { cient of variation } \\
(\%)\end{array}$ \\
\hline Guinea Savannah & 1544.6 & $2^{\text {nd }}$ & 14.9 & $4^{\text {th }}$ \\
Rainforest & 1709.6 & $1^{\text {st }}$ & 8.0 & $1^{\text {st }}$ \\
Montane & 1248.2 & $3^{\text {rd }}$ & 12.4 & $2^{\text {nd }}$ \\
Sahel Savannah & 633.9 & $4^{\text {th }}$ & 21.1 & $5^{\text {th }}$ \\
Sudan Savannah & 1248.2 & $3^{\text {rd }}$ & 13.1 & $3^{\text {rd }}$ \\
\hline
\end{tabular}

Source: own elaboration.
Table 2. Ranking of average annual temperature and coefficient of variation

\begin{tabular}{lllll}
\hline $\begin{array}{c}\text { Agro-ecological } \\
\text { zones }\end{array}$ & \multicolumn{2}{c}{$\begin{array}{c}\text { Ranking of average } \\
\text { annual temperature } \\
\left({ }^{\circ} \mathrm{C}\right)\end{array}$} & $\begin{array}{c}\text { Ranking of coeffi- } \\
\text { cient of variation } \\
(\%)\end{array}$ \\
\hline Guinea Savannah & 27.76 & $2^{\text {nd }}$ & 3.09 & $3^{\text {rd }}$ \\
Rainforest & 27.1 & $3^{\text {rd }}$ & 2.59 & $2^{\text {nd }}$ \\
Montane & 22.08 & $5^{\text {th }}$ & 3.39 & $4^{\text {th }}$ \\
Sahel Savannah & 28.78 & $1^{\text {st }}$ & 5.30 & $5^{\text {th }}$ \\
Sudan Savannah & 26.74 & $4^{\text {th }}$ & 2.58 & $1^{\text {st }}$ \\
\hline
\end{tabular}

Source: own elaboration.

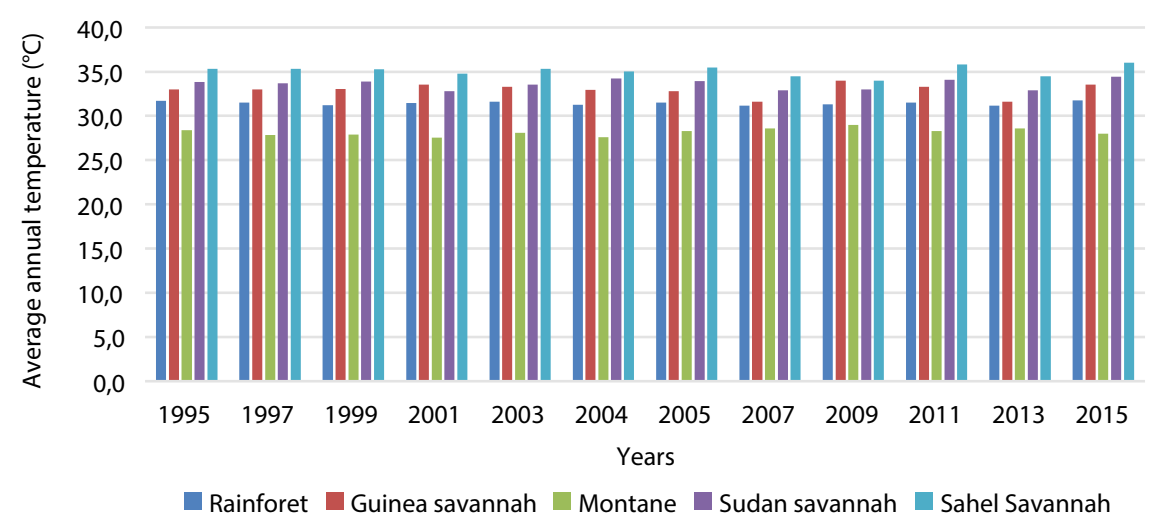

Fig. 2. Distribution of the average annual temperature by agro-ecological zones (1995-2015)

Source: result of data analysis, 2017. 
Sowunmi, F. A., Adeyemi, O. T., Bello, A. A. (2020). Effects of climatic variability on cassava production in Nigeria. J. Agribus. Rural Dev., 3(57), 327-335. http://dx.doi.org/10.17306/J.JARD.2020.01373

Table 3. Ranking of average annual relative humidity and coefficient of variation

\begin{tabular}{lllll}
\hline $\begin{array}{c}\text { Agro-ecological } \\
\text { zones }\end{array}$ & $\begin{array}{c}\text { Ranking of average } \\
\text { annual relative } \\
\text { humidity (\%) }\end{array}$ & $\begin{array}{c}\text { Ranking of coeffi- } \\
\text { cient of variation } \\
(\%)\end{array}$ \\
\hline Guinea Savannah & 64.7 & $2^{\text {nd }}$ & 4.68 & $5^{\text {th }}$ \\
Rainforest & 82.13 & $1^{\text {st }}$ & 2.06 & $1^{\text {st }}$ \\
Montane & 52.2 & $3^{\text {rd }}$ & 4.64 & $4^{\text {th }}$ \\
Sahel Savannah & 37.7 & $5^{\text {th }}$ & 2.97 & $2^{\text {nd }}$ \\
Sudan Savannah & 47.3 & $4^{\text {th }}$ & 3.14 & $3^{\text {rd }}$ \\
\hline
\end{tabular}

Source: own elaboration.

The total cassava output in the five agro-ecological zones from 1995 to 2015 was 736,783,068.9 MT. Rainforest and Guinea savannah accounted for $56.3 \%$ and $41.9 \%$ of the total cassava output respectively. The average annual cassava yield of the agro-ecological zones from 1995 to 2015 was $7.9 \mathrm{MT} / \mathrm{h}$. This is below the national average output of cassava per hectare of $13.04 \mathrm{MT} / \mathrm{ha}$ reported by the National Agricultural Extension and Research Liaison Services (NAERLS, 2010). The disparity between the value from the study and the national average yield (2007-2011) may be attributed to the difference in the period. The rainforest
Table 4. Ranking of average annual solar radiation and coefficient of variation

\begin{tabular}{lllll}
\hline $\begin{array}{c}\text { Agro-ecological } \\
\text { zones }\end{array}$ & $\begin{array}{c}\text { Ranking of average } \\
\text { annual radiation } \\
(\mathrm{mm})\end{array}$ & \multicolumn{2}{c}{$\begin{array}{c}\text { Ranking of coeffi- } \\
\text { cient of variation } \\
(\%)\end{array}$} \\
\hline Guinea Savannah & 20.01 & $4^{\text {th }}$ & 0.49 & $2^{\text {nd }}$ \\
Rainforest & 18.1 & $5^{\text {th }}$ & 0.46 & $1^{\text {st }}$ \\
Montane & 21.8 & $3^{\text {rd }}$ & 0.55 & $3^{\text {rd }}$ \\
Sahel Savannah & 23.16 & $1^{\text {st }}$ & 0.77 & $4^{\text {th }}$ \\
Sudan Savannah & 22.4 & $2^{\text {nd }}$ & 1.11 & $5^{\text {th }}$ \\
\hline
\end{tabular}

Source: own elaboration.

zone had the highest yield of cassava (12.1 MT/ha), while the Sahel savannah had the lowest $(3.5 \mathrm{MT} / \mathrm{ha})$ in the period of this study. Among the zones, only rainforest zones recorded the yield close to the national average yield of cassava. The sharp drop in the yield of cassava in major producing zones (see Fig. 3) may be attributed to the migration of herdsmen down south (the panacea to the effect of climate change) in search of feed for cattle and along the way, crops like cassava, maize and rice are consumed by cattle during the day and at night.

This has often resulted in heavy losses suffered by crop farmers and conflicts between crop farmers and the

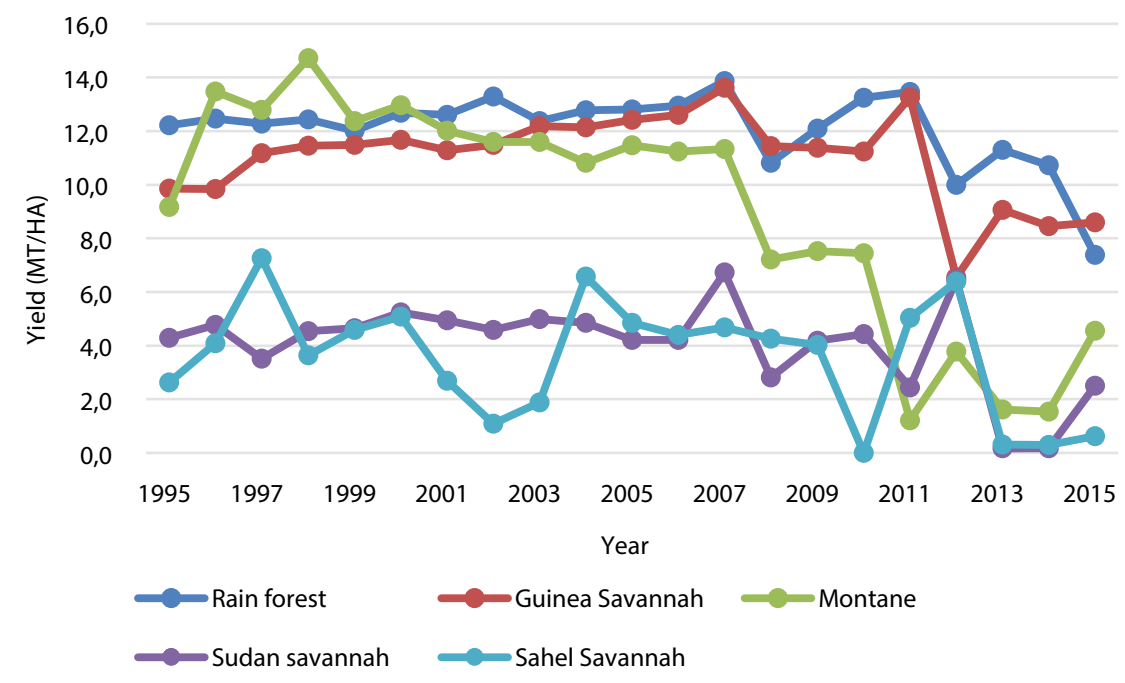

Fig. 3. Distribution of the cassava yield among the agro-ecological zones (1995-2015) Source: result of data analysis, 2017. 
Table 5. Ranking of average annual cassava output and coefficient of variation

\begin{tabular}{lcccc}
\hline $\begin{array}{c}\text { Agro-ecological } \\
\text { zones }\end{array}$ & $\begin{array}{c}\text { Ranking of average } \\
\text { annual cassava } \\
\text { output (MT/Ha) }\end{array}$ & \multicolumn{2}{c}{$\begin{array}{c}\text { Ranking of coeffi- } \\
\text { cient of variation } \\
(\%)\end{array}$} \\
\hline Guinea Savannah & 11 & $2^{\text {nd }}$ & 15.67 & $2^{\text {nd }}$ \\
Rainforest & 12.1 & $1^{\text {st }}$ & 11.89 & $1^{\text {st }}$ \\
Montane & 9.1 & $3^{\text {rd }}$ & 46.93 & $4^{\text {th }}$ \\
Sahel Savannah & 3.54 & $5^{\text {th }}$ & 61.17 & $5^{\text {th }}$ \\
Sudan Savannah & 4.03 & $4^{\text {th }}$ & 41.52 & $3^{\text {rd }}$ \\
\hline
\end{tabular}

Source: own elaboration.

herdsmen. The result shows that the rainforest zone had the least variability in average annual yield (11.89\%), while the Sahel savannah $(61.17 \%)$ had the highest/ largest dispersion of yield in the period of this study (see Table 5). This may be connected with the importance of water in cassava production. The results show that there were significant differences in climatic and agronomic variables among the agro-ecological zones but not among the years covered by the study (see Table 6). Also, there were significant variations in the cassava output, size of land cultivated and yield among the agroecological zones and the years under consideration. This may be attributed to the variations in suitability of different agro-ecological zones to cassava production and the importance of cassava to the nutrition of the inhabitants of each agro-ecological zone.

The results of the test for stationarity show that the variables behaviour was typical of time series data in terms of stationarity. The results of the Johansen test revealed that there exists a long-run relationship between the dependent variable and independent variables in all the agro-ecological zones. The need for the use of co-integration regression analysis, as confirmed by the Johansen test, was a result of the non-stationarity at the level of most of the variables in the agro-ecological zones. The result is explained based on the agroecological zones. Generally, the adjusted $\mathrm{R}^{2} \mathrm{~s}$ were low across the agro-ecological zones. This may be attributed to the fact that the values accounted for only the effects of climatic and agronomic factors captured in the

Table 6. Two-way ANOVA test results for climatic and agronomic variables among the agro-ecological zones and the years

\begin{tabular}{lccccc}
\hline \multicolumn{1}{c}{ Climatic/agronomic variable } & Sum of squares & Degree of freedom & Mean square error & $\mathrm{F}^{\text {cal }}$ & P-value \\
\hline Annual rainfall $(\mathrm{mm})$ & 15707407 & 4 & 3926852 & 151.5 & $0.000^{* * *}$ \\
Among the years & 524718.7 & 20 & 26235.94 & 1.01 & $0.46^{\mathrm{ns}}$ \\
Annual temperature $\left({ }^{\circ} \mathrm{C}\right)$ & 562.14 & 4 & 140.53 & 134.86 & $0.000^{* * *}$ \\
Among the years & 8.02 & 20 & 0.40 & 0.38 & $0.99^{\text {ns }}$ \\
Annual relative humidity $(\%)$ & 24837.28 & 4 & 6209.32 & 1509.6 & $0.000^{* * *}$ \\
Among the years & 98.24 & 20 & 4.91 & 1.19 & $0.28^{\text {ns }}$ \\
Annual solar radiation $\left(\mathrm{W} / \mathrm{m}^{2}\right)$ & 174.64 & 4 & 43.66 & 1522.57 & $0.000^{* * *}$ \\
Among years & 0.09 & 10 & 0.01 & 0.31 & $0.97^{\text {ns }}$ \\
Annual cassava output $(\mathrm{MT})$ & $7.57 \mathrm{E}+15$ & 4 & $1.89 \mathrm{E}+15$ & 205.3 & $0.000^{* * *}$ \\
Among the years & $3.73 \mathrm{E}+14$ & 20 & $1.87 \mathrm{E}+13$ & 2.02 & $0.014^{* *}$ \\
Annual land area cultivated $(\mathrm{Ha})$ & $5.73 \mathrm{E}+13$ & 4 & $1.43 \mathrm{E}+13$ & 98.98 & $0.000^{* * *}$ \\
Among the years & $1.03 \mathrm{E}+13$ & 20 & $5.15 \mathrm{E}+11$ & 3.56 & $0.000^{* * *}$ \\
Annual Yield (MT/Ha) & 1311.60 & 4 & 327.90 & 82.48 & $0.000^{* * *}$ \\
Among the years & 294.14 & 20 & 14.71 & 3.70 & $0.000^{* * *}$ \\
\hline
\end{tabular}

Source: result of data analysis, 2017. 
model. There are other important factors (like frequency of weeding, application of agrochemicals, the variety planted, farmers' contact with extension agents, access to credit, extent of compliance with new technology and experience of farmer in cassava cultivation among others) influencing cassava production. The Durbin Watson values show that there were no positive autocorrelations. The probability of the F-statistic of the results indicate that the models had a good fit $(p<0.01)$. The positive significance of annual farm size cultivated among the agro-ecological zones means that an increase in farm size leads to increase in cassava annual output. In the long-run, this is not encouraging because it is the only increased productivity that can justify farmers' investment and guarantee sustainable livelihood from farming. According to Ayinde et al. (2012), cassava production over the last half a century has largely been driven by land area expansion as opposed to improved cassava productivity. Table 7 shows that farm size (ha) and solar radiation were the factors that positively influenced cassava output in rainforest zone.

Two significant variables accounted for $23 \%$ variation in cassava output in the zone. The significance of the farm size is in agreement with Nwachukwu et al. (2012). In the Guinea savannah zone, the size of land cultivated (ha) was significant and positively influenced cassava output $(p<0.01)$, while annual rainfall was also significant but negatively influenced cassava output contrary to a priori expectations. This may be attributed to the limited number of variables (factors) captured in the model which is line with the research. There are other factors influencing cassava production in Nigeria. In the montane zone, the size of land cultivated positively influenced cassava output, while solar radiation

Table 7. Co-integration regression results for the agro-ecological zones

\begin{tabular}{lccccc}
\hline \multirow{2}{*}{ Variable } & \multicolumn{5}{c}{ Agro-ecological zones } \\
\cline { 2 - 6 } & Rainforest & Guinea Savannah & Montane & Sudan Savannah & Sahel Savannah \\
\hline Constant & 17.198 & 15.439 & 13.236 & -11.0587 & -120.720 \\
Land size (ha) & $(2.591)$ & $(2.401)$ & $(6.104140)$ & $(11.638)$ & $(60.0966)$ \\
& $2.50 \mathrm{E}-07^{* * *}$ & $2.33 \mathrm{E}-07^{* * *}$ & $2.98 \mathrm{E}-06^{* * *}$ & $5.16 \mathrm{E}-06^{* * *}$ & $0.750^{* * *}$ \\
Annual temperature $\left({ }^{\circ} \mathrm{C}\right)$ & $(3.88 \mathrm{E}-08)$ & $(6.48 \mathrm{E}-08)$ & $(5.53 \mathrm{E}-07)$ & $(1.11 \mathrm{E}-06)$ & $(0.0953)$ \\
& -0.0385 & 0.0639 & 0.0697 & 0.000124 & -0.000944 \\
Annual rainfall $(\mathrm{mm})$ & $(0.0595)$ & $(0.0845)$ & $(0.115)$ & $(0.00104)$ & $(4.450)$ \\
& $5.97 \mathrm{E}-05$ & $-0.00285^{* * *}$ & 0.00116 & $0.388^{*}$ & $2.0692^{* *}$ \\
Annual relative humidity $(\%)$ & $(0.000226)$ & $(0.000850)$ & $(0.000675)$ & $(0.194)$ & $(0.910)$ \\
& -0.0147 & -0.0107 & -0.0749 & 0.0355 & 6.634 \\
Annual solar radiation $\left(\mathrm{W} / \mathrm{m}^{2}\right)$ & $(0.023)$ & $(0.0180)$ & $(0.0450)$ & $(0.0938)$ & $(6.240)$ \\
& $0.0126^{*}$ & 0.00411 & $-0.0271^{* *}$ & -0.00220 & -0.154 \\
$\mathrm{R}^{-2}$ & $(0.00526)$ & $(0.00585)$ & $(0.0105)$ & $(0.0129)$ & $(0.145)$ \\
Probability of F-statistic & 0.0375 & 0.00101 & 0.0231 & 0.269 & 24.318
\end{tabular}

Dependent variable: cassava output (metric tonnes).

${ }^{*, * *, * * *}$ indicate statistical significance at $10 \%, 5 \%$ and $1 \%$ levels respectively. 
negatively influenced cassava production. The negative relationship may be attributed to an increase in transpiration and abiotic stress as a result of increased solar radiation. Ferrante and Mariani (2018) revealed that abiotic stresses directly affect plant growth and development. In agriculture, sub-optimal values of temperature, light intensity, and relative humidity can limit crop yield and reduce product quality. Temperature has a direct effect on whole plant metabolism, and low or high temperatures can reduce growth or induce crop damage. In Sudan savannah and Sahel savannah zones, size of land cultivated (ha) and annual rainfall were the factors that positively influenced cassava output. However, an increase in the land cultivated should be guided by improved productivity. According to Spore CTA (2015), an arable land expansion approach has been the source of increase in food production as against increase in productivity that can enhance the farmers' commitment and give good returns to their efforts.

\section{CONCLUSIONS AND RECOMMENDATIONS}

The study showed that climatic factors influenced cassava output in Nigeria. The effect of the variable(s) differs from one agro-ecological zone to the other. This also translates to the output of cassava which was also agroecological zone specific, as it decreases northwards. However, the implementation of a positive relationship between farm size and cassava output across the agroecological zones should be guided by improved productivity to justify the resources utilised. There is a need for extension agents to monitor and make available to farmers information on the weather (through collaboration with the Nigerian Meteorological Agency) and recent technology in terms of high yielding cassava varieties. Increasing farm sizes guided by improved productivity through the use of improved cultivars and adoption of modern agronomic practices is recommended for the rainforest and Guinea savannah zones (suitable for cassava production) to enhance the returns on farmers' investment; utilisation of affordable irrigation (occasional flooding of farmland with the right quantity of water) and the adoption of climate-smart agriculture by cassava farmers to boost production in Sudan savannah and Sahel savannah is advised. Additionally, the increase of farmland should be guided by improved cassava productivity driven by the use of improved and drought resistant cultivars, and appropriate agronomic practices should be midwifed by committed agricultural extension agents.

\section{REFERENCES}

Amikuzono, J., Donkoh, S.A. (2012). Climate variability and Yields of Major Staple Food Crops in Northern Ghana. Am. Crop Sci. J., 20(2), 349-360.

Amos, T.T., Thompson, O.A. (2015). Climate Change and Cocoa Production in the Tropical Rain Forest Ecological Zone of Ondo State, Nigeria. J. Env. Earth Sci., 5(1), $36-41$.

Anyanwu, S., Offor, S., Adesope, O., Ibekwe, C. (2013). Structure and Growth of the Gross Domestic Product (1960-2008): Implications for Small-scale Enterprise in Nigeria. Glob. Adv. Res. J. Manag. Bus. Stud., 2(6), 342-348.

Ayanlade, O., Theophilus, O., Orimoogunje, O. (2010). Impacts of Climate Variability on Tuber Crops in Guinea Savannah Part of Nigeria: A GIS Approach. J. Geogr. Geol., 2(1), 27-35.

Ayinde, E., Ojehomon, T., Ebihomon, V., Daramola, S., Akindeji, F. (2011). Evaluation of Effect of Climate Change on Rice Production in Niger State Nigeria. Ethiop. J. Env. Stud. Manag., 6, 763-773.

Bareja, B. (2019). Climatic Factors can Promote or Inhibit Crop Growth, Development and Productivity. Retrieved from: https://www.cropsreview.com/climatic-factors.html

Ben, B. (2019). Climatic Factors can Promote or Inhibit Crop Growth, Development and Productivity. Retrieved from: https://www.cropsreview.com/climatic-factors.html

Chikezie, I.U., Ohajianya, D., Orebiyi, J., Ehirim, N., HenriUkoha, A., Nwaiwu, I., Ajah, E., Essien, U., Anthony, G., Oshaji, I. (2015). Effect of Climate Change on Food Production in Southeast Nigeria: A Co-integration Model Approach. Int. J. Weath. Clim. Chan. Cons. Res., 2(1), 47-56.

Climate Change 2001. Synthesis report (2001). A Contribution of Working Groups I, II, III to the Third Assessment Report of the Intergovernmental Panel on Climate Change. Cambridge, United Kingdom - New York, USA: Cambridge University Press. Retrieved from: https:// www.ipcc.ch/site/assets/uploads/2018/05/SYR_TAR_ full_report.pdf

FAO (1995). Cassava development in Nigeria. Rome: Food and Agricultural Organization. Retrieved from: http://www.fao. org/3/a0154e/A0154E06.HTM

FAO (2013). Cassava: A guide to sustainable production intensification. Rome: Food and Agriculture Organization of the United Nations. Retrieved from: http://www.fao. org/3/a-i3278e.pdf 
FAO (2015). FAO statistical pocketbook. World Food and Agriculture. Rome: Food and Agriculture Organization of the United Nations. Retrieved from: http://www.fao.org/3/ai4691e.pdf

Fauquet, C., Fargette, D. (1990). African cassava mosaic virus: etiology, epidemiology and control. Plant Dis., 74, 404-411.

Ferrante, A., Mariani, L. (2018). Agronomic Management for Enhancing Plant Tolerance to Abiotic Stresses: High and Low Values of Temperature, Light Intensity, and Relative Humidity. Horticulture, 4(3), 1-19.

Gebrehiwot, T., van der Veen, A. (2013). Farm Level Adaptation to Climate Change: The Case of Farmer's in the Ethiopian Highlands. Env. Manag., 52, 29-44. Retrieved from: https://link.springer.com/journal/267

Girma, E., Tino, J., Wayessa, G. (2016). Rainfall trend variability analysis in Setema-Gatira area of Jimma, Southwestern Ethiopia. Afr. J. Agric. Res., 11(32), 3037-3045.

Intergovernmental Panel on Climate Change (2001). Climate Change 2001: The Scientific Basis. Contribution of Working Group I to the Third Assessment Report of the Intergovernmental Panel on Climate Change. Cambridge, United Kingdom and New York, USA: Cambridge University Press.

International Fund for Agricultural Development Report (2016). Rural poverty in Nigeria. Retrieved from: https:// www.bridge.ids.ac.uk/global-resources/resource/A101269

Kansiime, M., Wambugu, S., Shisanya, C. (2013). Perceived and actual rainfall trends and Variability in Eastern Uganda: Implications for community preparedness and response. J. Nat. Sci. Res., 3(8), 179-193.

Kimengsi, J., Ngong, J.T. (2013). Climate Variability and Cocoa Production in Meme Division of Cameroon: Agricultural Development Policy Options. Green. J. Agric. Sci., 3(8), 606-617.

Mendelsohn, R. (2012). The Economics of Adaptation to Climate Change in Developing Countries. Clim. Chang. Econ., 3(2), 1-21.
NAERLS (2010). Agricultural performance survey of wet season in Nigeria. Zaria, Nigeria: National Agricultural Extension and Research Liaison Services. Retrieved from: https://orr.naerls.gov.ng/national-agricultural-extension-andresearch-liaison-services-naerls/resources?page $=22$

National Agricultural Extension and Research Liaison Services (2010). Agricultural performance survey of wet season in Nigeria. Zaria, Nigeria. Retrieved from http://www. yieldgap.org/nigeria

Nwachukwu, I., Ezeh, C., Emerole, C. (2012). Effect of Climate Change on Cocoa Productivity in Nigeria. Afr. Crop Sci. J., 20, 487-491.

Nyatuame, M., Owusu-Gyimah, V., Ampiaw, F. (2014). Statistical analysis of rainfall trend for Volta region in Ghana. Int. J. Atmos. Sci., 2014, 1-11.

Ogungbenro, S.T., Morakinyo, T.E. (2014). Rainfall distribution and change detection among the climatic zones in $\mathrm{Ni}$ geria. Weather Clim. Extrem., 5-6, 1-6.

Oluyole, A.K. (2010). The Effect of Weather on Cocoa Production in Different Agro- Ecological Zones In Nigeria. World J. Agric. Sci., 6(5), 609-614.

Orefi, A. (2010). Long Run Relationship between Sorghum Yield, Rainfall and Producer Price in Nigeria. Int. J. Food Agric. Econ., 3(1), 77-86.

Philip, T., Taylor, D., Sanni, L., Okechukwu, R., Ezedinma, C., Akoroda, M., Lemchi, J., llona, P., Ogbe, F., Okoro, E., Dixon, A.G.O. (2005). The Nigerian cassava industry: Statistical handbook. Ibadan, Nigeria: International Institute of Tropical Agriculture (IITA).

Sowunmi, A., Akintola, J. (2010). Effect of Climatic variability on Maize Production in Nigeria. Res. J. Env. Earth Sci., 2(1), 19-30.

Spore CTA (2015). The magazine for agricultural and rural development in ACP countries, No 176, June - July 2015, pp. 4 and 20; http://spore.cta.int

Toshichika, L., Navin, R. (2015). How do weather and climate influence cropping area and intensity. Glob. Food Sec., 4, 46-50. 